\title{
Molecular mechanisms of pluripotency and reprogramming
}

\author{
Jie $\mathrm{Na}^{1 *}$, Jordan Plews ${ }^{2}$, Jianliang Li², Patompon Wongtrakoongate ${ }^{2}$, Timo Tuuri ${ }^{2}$, Anis Feki ${ }^{3}$, Peter W Andrews ${ }^{2}$ \\ and Christian Unger*
}

\begin{abstract}
Pluripotent stem cells are able to form any terminally differentiated cell. They have opened new doors for experimental and therapeutic studies to understand early development and to cure degenerative diseases in a way not previously possible. Nevertheless, it remains important to resolve and define the mechanisms underlying pluripotent stem cells, as that understanding will impact strongly on future medical applications. The capture of pluripotent stem cells in a dish is bound to several landmark discoveries, from the initial culture and phenotyping of pluripotent embryonal carcinoma cells to the recent induction of pluripotency in somatic cells. On this developmental time line, key transcription factors, such as Oct4, Sox2 or Nanog, have been revealed not only to regulate but also to functionally induce pluripotency. These early master regulators of development control developmental signalling pathways that affect the cell cycle, regulate gene expression, modulate the epigenetic state and repair DNA damage. Besides transcription factors, microRNAs have recently been shown to play important roles in gene expression and are embedded into the regulatory network orchestrating cellular development. However, there are species-specific differences in pluripotent cells, such as surface marker expression and growth factor requirements. Such differences and their underlying developmental pathways require clear definition and have major impacts on the preclinical test bed of pluripotent cells.
\end{abstract}

*Correspondence: jie.na@tsinghua.edu.cn; C.Unger@sheffield.ac.uk 'School of Medicine, Tsinghua University, Beijing, 100084 China

2Department of Biomedical Sciences, University of Sheffield, Sheffield, S10 2TN, UK Full list of author information is available at the end of the article

\section{Defining pluripotent stem cells}

Discovery of pluripotent stem cells - embryonal carcinoma cells

Pluripotency is the potential of stem cells to give rise to any cell of the embryo proper. The study of pluripotent stem cells from both mouse and human began with the study of teratocarcinomas, germ cell tumours that occur predominantly in the testis and constitute the most common cancer of young men. In 1954, Stevens and Little [1] found that males of the 129 mouse strain developed testicular teratocarcinomas at a significant rate. This finding opened the way for detailed studies of these peculiar cancers, which may contain a haphazard array of almost any somatic cell type found in the developing embryo [2]. The stem cells of these tumours are embryonal carcinoma (EC) cells, which express characteristics, including a developmental potential, similar to those of the inner cell mass (ICM) of the early embryo [3]. Experience with these pluripotent malignant EC cells from mouse teratocarcinomas provided the basis for the derivation of embryonic stem (ES) cells from explants of mouse blastocysts independently $[4,5]$. Indeed, mouse EC and ES cells closely resemble one another, expressing similar markers and, in some cases, similar developmental potentials, although a report of germ line derivation from mouse EC cells in chimeras [6] has never been confirmed.

\section{Pluripotent cells in the embryo - inner cell mass cells}

At the morula stage, totipotent cells start to specialize as they form the blastocyst, comprising an outer layer of cells, the trophectoderm (TE), and a group of pluripotent cells, the ICM. While the TE will develop into placental tissues, the ICM gives rise to all cells of the embryo proper as well as several extraembryonic tissues. The earliest factors known to regulate the formation of pluripotent ICM cells are OCT4 and NANOG [7-9]. Without OCT4, epiblast cells fail to form and ES cells cannot be derived, while NANOG is required for the germline formation [7-9].

Recent studies in the laboratory mouse have provided insights into the molecular mechanisms and key factors regulating the specification of ICM and TE lineages. At 
the morula stage, cells choose their fate depending on their position and polarity [10]. In outside cells, Yap, the co-activator for transcription factor Tead4, localises in the nucleus and increases Tead4 activity. Tead4 subsequently activates the TE master factor $\mathrm{Cdx} 2$, which determines the cell fate [10]. Embryos lacking either Tead4 or Cdx2 fail to produce functional trophectodermal tissue but ICM cells remain intact and ES cells can be derived [11,12]. The dominance of $\mathrm{Cdx} 2$ suppresses Oct4 expression in the outer cells and restricts its expression in the inner cells, which become ICM cells at the blastocyst stage. Thus, the counter-activity between Oct4 and Cdx2 allows the segregation of the first two embryonic lineages [13]. It is noteworthy that this mechanism might be specific to mouse as in both rhesus monkey and human, the expression of NANOG is reported to be restricted to the ICM, but OCT4 was detected in TE as well as ICM cells [14].

\section{Embryonic stem cells and species differences}

Although human ES cells were not derived until 1998 [15], studies of EC cells from human testicular cancers demonstrated significant differences between mouse and human EC cells and, by implication, ES cells [16-19]. Most notably, the cell surface antigens SSEA1 and SSEA3 and 4 are expressed differently: mouse EC and ES cells are SSEA1(+)/SSEA3(-)/SSEA4(-), whereas human EC cells are SSEA1(-)/SSEA3(+)/SSEA4(+). This surface antigen phenotype of human EC cells is similar to that of human ES cells $[15,20]$ and human ICM cells [21]. A large panel of surface antigen markers and characteristic gene expression patterns for human ES cells has now been identified [20]. A further distinction between human and mouse ES cells, which was also evident in EC cells, is the capacity of human EC and ES cells to generate trophoblastic cells [16]. This does not usually occur in mouse EC and ES cells, except after genetic manipulation [13]. Especially in the mouse, a clear distinction between ES cells and epiblast stem cells is being made [22-24]. Recent work with human induced pluripotent stem (iPS) and ES cells has produced cells more similar to mouse ES cells by maintenance in low oxygen conditions, or overexpression of OCT4, KLF4 and KLF2 and inhibition of glycogen synthase kinase 3 and mitogen activated protein kinase $[25,26]$. These culture conditions with physiological oxygen levels $(5 \%)$ are able to maintain more naïve ES cells [26]. However, it remains to be seen if this reduction of oxidative stress is important for the use of pluripotent stem cells in therapeutic applications.

\section{Inducing pluripotent stem cells from somatic cells The history of reprogramming}

Through early embryonic development and cellular differentiation, cells progressively lose developmental potency and choose a specific fate [27]. However, the seminal somatic cell nuclear transfer studies of Briggs and King [28] showed that blastula cell nuclei retain the genetic information required for pluripotency when injected into enucleated frog oocytes. This phenomenon was investigated further by Gurdon and Uehlinger [29], who demonstrated that even more differentiated intestinal cells were capable of directing development into adult frogs following somatic cell nuclear transfer, albeit at low efficiency (approximately 1\%). These early cloning experiments proved that nuclei from terminally differentiated cells are capable of generating viable cloned animals, and formed the basis of later mammalian cloning experiments [30].

The creation of the first cloned sheep, 'Dolly', by Wilmut and colleagues [30] together with many other later successful mammalian cloning attempts convincingly demonstrated that the developmental restrictions established during differentiation are due to reversible changes in the epigenome, rather than to permanent modifications to the genome [31]. Fusing somatic cells with ES cells or exposing them to EC cell extracts can also generate cells with pluripotent phenotypes [32,33]. Thus, the cytoplasm of the oocyte and pluripotent stem cells must contain factors necessary for reprogramming. These studies indicate that key factors that are important for pluripotency within germ cells, early embryos and ES cells may also have the reprogramming ability.

Studies with somatic cells demonstrated that one could redirect cell fate by forced expression of a single lineagespecific transcription factor. Weintraub and colleagues [34] found that overexpression of $M y o D$ is sufficient to convert fibroblasts into muscle cells, while mature B cells can be reprogrammed into macrophages by enforced expression of C/EBP $\alpha$ or $C / E B P \beta$ within 3 to 4 days [35]. These studies highlighted the possibility that transdifferentiation or even dedifferentiation may be mediated by a few defined factors.

\section{Induced pluripotency with key factors}

In 2006, the ground breaking work by Takahashi and Yamanaka [36] demonstrated that forced expression of four ES cell factors (Oct4, Sox2, cMyc, and Klf4) in fibroblast cells can reprogram them to a pluripotent state. The most efficient method to make iPS cells is through viral transduction due to their high integration efficiency $[37,38]$. In properly reprogrammed iPS cells, the transgene driven by the viral promoter should be completely silenced [39]. Failure of silencing indicates incomplete reprogramming and raises the danger of carcinogenesis by the oncogene $c M y c$ [39]. To avoid insertional mutagenesis and transgene reactivation, associated with the viral approach, other methods that do not alter the genome have been developed, such as non-integrating 
episomal vectors [40], minicircle vectors [41] and the PiggyBac transposon system [42,43]. Transgene-free iPS cells were successfully derived but with lower efficiency. The most attractive approach may be using permeable recombinant proteins [44-46], as this eliminates the possibility of genome alteration by introduced foreign DNA. This would also allow the dosage to be controlled and the exposure time of each factor optimised, although this method has not been widely successfully applied.

\section{Molecular mechanisms of reprogramming}

Re-establishing pluripotency in a somatic cell is a complicated process. The most important changes include the activation of an ES-cell-specific transcription network, re-setting the epigenetic landscape, alteration of the cell cycle signature and overcoming the DNA damage response triggered by these drastic changes.

\section{ES-cell-specific transcription factors and transcription network}

The four reprogramming factors discovered by Takahashi and Yamanaka, Oct4, Sox2, Klf4 and $c M y c$, all have vital roles in early embryogenesis and ES cells [36]. The POU domain transcription factor Oct4 is required for the pluripotency of ICM cells and ES cells and is an essential factor in most reprogramming experiments [7]. Although in one recent report the nuclear receptor $\mathrm{Nr} 5 \mathrm{a} 2$ was able to replace Oct4, the underlying mechanism appeared to be that Nr5a2 activates Oct4 and Nanog by binding to their promoters and upregulating their expression [47]. A protein interaction study in mouse ES cells showed that Oct4 binds to as many as 92 proteins. Many of these are only expressed by ES cells, but some are ubiquitously expressed in all cells, such as the nucleosome remodelling and deacetylase (NuRD) complex [48]. The cellular protein environment can have a significant influence on reprogramming. For example, when fusing a somatic cell with an ES cell, or transfering its nucleus into an oocyte, where many OCT4 binding partners naturally exist, reprogramming is much quicker and more efficient $[32,49]$. By choosing adult cell types that express more OCT4 interacting proteins, such as neural stem cells and melanocytes where SOX2, a Sry-related high mobility group box transcription factor, is present, one can obtain iPS cells with higher efficiency and in a shorter time frame [50,51].

In mouse ES cells, it has been shown that Sox2 closely works with Oct4 to regulate the transcription of key pluripotency genes, including Oct4, Sox2 and Nanog [52]. Without Sox2, ES cells cannot effectively activate the OctSox enhancers. However, higher levels of Oct4 were able to compensate for the absence of Sox 2 and maintain the ES cell phenotype [52]. During reprogramming of mouse fibroblast cells, Sox2 can be replaced by transforming growth factor- $\beta$ inhibitors, which have been shown to induce both Nanog and $c M y c$ expression [53,54]. Thus, it appears that Oct 4 could work with factors other than Sox2 to achieve cellular reprogramming.

The Krüppel-like zinc finger transcription factor Klf4 is highly expressed by mouse ES cells and can cooperate with the Oct4-Sox2 complex to activate certain ES-cellspecific genes such as Lefty1 [55]. It plays an important role in the pluripotency circuitry by regulating the expression of Sox2 and Nanog [56,57]. By overexpressing $K l f 4$, mouse epiblast derived stem cells (epistem cells) can be returned to the naïve ES cell state [58]. Similarly, increasing the expression of KLF4 and OCT4 or KLF4 and KLF2 enabled human ES cells and iPS cells to exhibit mouse ES cell characteristics, including the ability to grow in leukemia inhibitory factor (LIF) and 2i (ERK1/2 and glycogen synthase kinase 3 inhibitors) as well as the activation of both $\mathrm{X}$ chromosomes [25]. iPS cells reprogrammed using Oct4, Sox2 and Klf4 but without $c M y c$ showed lower tumorigenicity [59]. The above evidence suggests that Klf4 can prompt cells to acquire a more authentic and naïve ES cell phenotype.

$c M y c$ is an oncogene and seems to act as a catalyst in the reprogramming process as it can significantly increase the efficiency of iPS cell generation [59]. In ES cells, cMYC was found to occupy promoters of active genes and ES-cell-specific microRNAs (miRNAs), including miR-291-3p, miR-294, miR-295, miR-141, miR-200, and miR-429 [57,60,61]. Overexpression of these miRNAs either promoted iPS cell generation or reduced mouse ES cell differentiation [60,61]. cMYC can recruit multiple chromatin remodellers, such as histone acetyltransferase GCN5 and histone demethylase Lid, to create an open chromatin state. This allows the ectopically expressed ES cell transcription factors to activate their target genes more easily [62]. The negative side of cMYC's action is tumorigenecity [59]. Thus, iPS cells created using $c M y c$ need to be carefully scrutinised to ensure the silence of this oncogene.

NANOG and LIN28 can replace KLF4 and $c M Y C$ to reprogram human fibroblast cells to iPS cells [38]. Nanog is a core member of the pluripotency circuitry [57] and constitutive expression is sufficient to support selfrenewal of mouse ES cells in the absence of LIF [8]. Nanog is also required for germline development [63]. Although not absolutely required for reprogramming, including Nanog increased the efficiency of iPS generation [64].

LIN28 is an evolutionarily conserved RNA binding protein highly enriched in mouse and human ES cells $[20,65]$. Its function in reprogramming will be discussed in more detail later in the section on miRNAs.

Studies in mouse ES cells revealed that the promoter region of actively transcribed genes was often occupied 
by multiple key pluripotency transcription factors [57]. Moreover, these factors can self-regulate to reinforce the undifferentiated state. Different combinations of transcription factors may control distinct subgroups of genes [57]. Thus, to activate the entire ES cell transcriptome, not only is the cooperation of key factors (namely OCT4, SOX2, KLF4 and cMYC) required, but their levels and ratio of expression are also critical [66]. Two very recent publications reported that reprogramming factors can also orchestrate a mesenchymal to epithelial transition, which is important for the initiation stage of reprogramming $[67,68]$. Down-regulation of epithelialspecific factors, such as E-CADHERIN, PAR3 and CRB3, suppressed the formation of iPS colonies [68], while suppression of transforming growth factor- $\beta$ signalling, which is important for epithelial to mesenchymal transition, improved reprogramming efficiency [67].

\section{Epigenetics}

The chromatin and DNA modification machinery play critical roles during reprogramming as the epigenetic landscape of a somatic cell needs to be completely reshaped to ES-cell-like states. The epigenome of ES cells is characterised by the demethylation of the promoter regions of key pluripotency transcription factors, such as Oct4, Sox2 and Nanog, as well as bivalent chromatin modifications on developmentally important transcription factors [69]. This ensures a high level of expression of the core factors that maintain pluripotency. At the same time cells reside in a poised state, ready to differentiate in response to developmental signals [69].

During reprogramming, the genome loci occupied by histone $\mathrm{H} 3$ lysine 4 trimethylation (H3K4me3) and histone $\mathrm{H} 3$ lysine 27 trimethylation, which are commonly associated with active and repressive gene expression, respectively, appears to change in accordance with the dedifferentiation process. For example, H3K4me3 marking was lost from promoter regions of mouse embryonic fibroblast-specific genes, but increased significantly on the promoters/enhancers of the ES-cellspecific genes Fgf4, Oct4 and Nanog [70]. Moreover, the DNA methylation was erased at promoters of pluripotency genes in fully reprogrammed cells but not in mouse embryonic fibroblasts or partially reprogrammed cells [70]. To date, many cell types, including some cancer cells, have been shown to be amenable for reprogramming, reflecting the plasticity of the epigenome [51,64,71,72]. Different cell types may possess different degrees of plasticity; compared to skin fibroblast cells, epithelial cell types, such as keratinocytes, liver and stomach cells, can be converted to iPS cells with higher efficiency [72,73]. In addition, a hierarchy of epigenetic states may correlate with a cell's differentiation stage. It was found that in the hematopoietic lineage, stem and progenitor cells give rise to iPS cells much more efficiently than terminally differentiated $\mathrm{B}$ and $\mathrm{T}$ cells [74]. Manipulating the DNA and chromatin modifications can greatly facilitate iPS cell formation. The DNA methyltransferase inhibitor 5'-azacytidine and the histone deacetylase inhibitor valproic acid increased the reprogramming efficiency 5 -fold and more than 100-fold, respectively [75]. BIX-01294, an inhibitor of the G9a histone methyltransferase, was able to substitute cMyc to induce pluripotency from neural stem cells together with Oct4 and Klf4 [76].

Two recent studies observed that early passage iPS cells still retain some degree of somatic cell memory, which can influence the differentiation preference of these cells $[77,78]$. However, these remaining epigenetic memories appeared to attenuate after continuous in vitro culture $[77,78]$. In addition, some mouse iPS cell lines displayed aberrant silencing of imprinted genes such as the Dlk1Dio3 cluster. These lines showed poor contribution to chimeric animals and were not germline competent $[79,80]$. The ability of germline transmission is also influenced by the combination of reprogramming factors. Mouse iPS cells generated by Oct4, Sox2, Klf4 and Tbx3 were found to contribute to the germ tissue with higher efficiency compared to iPS cells reprogrammed by Oct4, Sox2, and Klf4 or Oct4, Sox2, and Esrrb [81]. Imprinting abnormalities were found in human iPS cells, including the biallelic expression of H19 and KCNQ10T1 [82]. The Fragile X syndrome gene (FX) was active in ES cells derived from embryos with the FX mutation but remained silenced in iPS cells reprogrammed from FXfibroblast cells [83]. Thus, if iPS cells and their derivatives are to be used to model human diseases or in therapeutic applications, several aspects need to be carefully evaluated: the tissue origin and passage number; the reprogramming factors used; the status of imprinted genes; and the histone modification of disease-related genome loci.

\section{microRNAs and reprogramming}

miRNAs are approximately 22-nucleotide RNAs that bind to complementary sequences in the 3' untranslated regions of protein coding mRNAs to regulate their degradation or translation [84]. As important modulators of developmental timing and stem cell differentiation, they have, unsurprisingly, also been implicated in reprogramming. The well-known Let-7 family miRNAs are ubiquitously expressed in somatic cells and upregulated upon ES cell differentiation. Their mRNA targets include those encoding cell cycle regulators such as K-RAS, cMYC, CDC25A, cyclinD1, and stem cell factors HMGA2, Mlin-41 and IMP-1 [82,85]. Lin28 is an ES-cell-specific factor whose major function is to keep let-7 miRNAs at low level by promoting their degradation 
$[86,87]$. Indeed, an insightful study by Hanna and colleagues [64] showed that overexpression of Lin28 shortened the cell cycle in monoclonal B cells and sped up iPS cell generation. In another report, the ES-cellspecific miRNA miR-294 increased the efficiency of iPS cell generation by approximately tenfold when introduced together with Oct4, Sox 2 and Klf4, but not when $c M y c$ was present [60]. The authors then found that miR-294 was a downstream target of cMyc [60]. Interestingly, using a green fluorescent protein (GFP) reporter driven by the Oct4 promoter, most colonies from the Oct4, Sox2, Klf4 and miR-294 group were positive for GFP expression, indicating that they are more homogenous iPS cell colonies. In contrast, cMyc significantly increased the number of GFP-positive as well as GFP-negative colonies when added together with Oct4, Sox2, and Klf4 [60]. This study suggests that ES-cell-specific miRNAs are able to fine tune the reprogramming process and may be useful to reduce the heterogeneity in iPS cells.

\section{DNA damage}

The cellular stress imposed by reprogramming can trigger the DNA damage response and subsequently result in cell cycle arrest and senescence. Only a few cells were able to overcome this barrier and become iPS cells. This may be the reason why the efficiency of reprogramming is extremely low. Several studies have demonstrated that when key components (such as p53 and p21) of the DNA damage machinery were deleted, the rate of iPS cell generation is significantly increased [88-94]. The detailed mechanism will be discussed by a separate review in this issue. It has been shown recently that vitamin $C$ supplementation can improve reprogramming efficiency by alleviating p53-induced cell senescence and synergizing with epigenetic regulators [95]. However, it is dangerous to obtain rapid reprogramming at the cost of inappropriate suppression of DNA damage pathways. SV40 large T can disrupt the nuclear DNArepair foci [96]. When it was added together with the four factors to reprogramme human fibroblast cells, iPS cell colonies emerged after 8 days but many of those iPS cells gained chromosomal abnormalities [97]. Thus, the intricate balance between safeguarding genome integrity and changing cell fate must be carefully maintained during reprogramming.

\section{Future challenges}

By elucidating the mechanisms of how pluripotency factors interact with one another and with the genome, it should be possible to devise means to significantly improve reprogramming efficiency and speed. New interaction partners or pathways might provide explanations to species differences and provide the means to a defined in vitro culture of pluripotent cells. It remains to be seen whether human ES cells resemble an ICM or epiblast like stage, and whether or not that has any impact on their clinical applicability.

Several articles have reported that iPS cells are notably distinct from ES cells in terms of their gene expression, epigenetic profile, proliferative capacity and the susceptibility of their differentiated progeny to cellular senescence and apoptosis [82,83,98-100]. These differences need to be clearly defined and may become of importance if developmental research should be translated into the clinic. The definition of the cells in terms of pluripotency markers and the reproducibility of cell culture conditions will have a major impact on possible future therapeutical applications. There is a need for standardization in clinical protocols, which profits from fully defined media conditions allowing reproducible growth of pluripotent cells. Initial requirements, such as good manufacturing practice, are the same for human ES cells and human iPS cells [101]. However, iPS cells are certainly a step further away from clinical application than ES cells, as more parameters are yet to be characterized. First among these are issues of safety and efficacy. The earliest methods for the derivation of iPS cells used viral vectors, which may induce insertional mutagenesis and transgene reactivation. Alternative methods for inducing pluripotency without the use of gene insertion have been reported, though their efficiency needs improvement. Other safety criteria, such as long-term karyotypic stability, appropriate in situ localization, and potential differentiation of somatic cells derived from iPS cells, are to be investigated $[102,103]$.

\section{Conclusions}

Ultimately, understanding of the underlying mechanisms of pluripotency will be able to guide the way to a safe and new cell-based medicine. The modelling of disease and normal development, if well understood, provides the chance to design completely new treatment modalities. Being autologous cells, iPS cells especially allow for a new individualised approach and are able to create a cell model as well as a cell source for each and every person.

\section{Abbreviations}

EC, embryonal carcinoma; ES, embryonic stem; FX, fragile X; GFP, green fluorescent protein; H3K4me3, histone $\mathrm{H} 3$ lysine 4 trimethylation; ICM, inner cell mass; iPS, induced pluripotent stem; LIF, leukemia inhibitory factor; miRNA, microRNA; TE, trophoectoderm.

\section{Competing interests}

The authors declare that they have no competing interests.

\section{Author details}

'School of Medicine, Tsinghua University, Beijing, 100084 China. ${ }^{2}$ Department of Biomedical Sciences, University of Sheffield, Sheffield, S10 2TN, UK.

${ }^{3}$ Department of Obstetrics and Gynecology, Geneva University Hospitals, 1211 Geneva, Switzerland.

Published: 25 October 2010 


\section{References}

1. Stevens LC, Little CC: Spontaneous testicular teratomas in an inbred strain of mice. Proc Natl Acad Sci U S A 1954, 40:1080-1087.

2. Stevens LC: The biology of teratomas. Adv Morphog 1967, 6:1-31.

3. Solter D: From teratocarcinomas to embryonic stem cells and beyond: a history of embryonic stem cell research. Nat Rev Genet 2006, 7:319-327.

4. Martin GR: Isolation of a pluripotent cell line from early mouse embryos cultured in medium conditioned by teratocarcinoma stem cells. Proc Natl Acad SciU SA 1981, 78:7634-7638.

5. Evans MJ, Kaufman MH: Establishment in culture of pluripotential cells from mouse embryos. Nature 1981, 292:154-156.

6. Mintz B, Illmensee K: Normal genetically mosaic mice produced from malignant teratocarcinoma cells. Proc Natl Acad Sci U S A 1975 72:3585-3589.

7. Nichols J, Zevnik B, Anastassiadis K, Niwa H, Klewe-Nebenius D, Chambers I, Scholer H, Smith A: Formation of pluripotent stem cells in the mammalian embryo depends on the POU transcription factor Oct4. Cell 1998, 95:379-391

8. Chambers I, Colby D, Robertson M, Nichols J, Lee S, Tweedie S, Smith A: Functional expression cloning of Nanog, a pluripotency sustaining factor in embryonic stem cells. Cell 2003, 113:643-655.

9. Mitsui K, Tokuzawa Y, Itoh H, Segawa K, Murakami M, Takahashi K, Maruyama M, Maeda M, Yamanaka S: The homeoprotein Nanog is required for maintenance of pluripotency in mouse epiblast and ES cells. Cell 2003, 113:631-642.

10. Nishioka N, Inoue K, Adachi K, Kiyonari H, Ota M, Ralston A, Yabuta N, Hirahara S, Stephenson RO, Ogonuki N, Makita R, Kurihara H, Morin-Kensicki EM, Nojima H, Rossant J, Nakao K, Niwa H, Sasaki H: The Hippo signaling pathway components Lats and Yap pattern Tead4 activity to distinguish mouse trophectoderm from inner cell mass. Dev Cell 2009, 16:398-410.

11. Yagi R, Kohn MJ, Karavanova I, Kaneko KJ, Vullhorst D, DePamphilis ML, Buonanno A: Transcription factor TEAD4 specifies the trophectoderm lineage at the beginning of mammalian development. Development 2007 134:3827-3836.

12. Strumpf D, Mao CA, Yamanaka Y, Ralston A, Chawengsaksophak K, Beck F, Rossant J: Cdx2 is required for correct cell fate specification and differentiation of trophectoderm in the mouse blastocyst. Development 2005, 132:2093-2102.

13. Niwa H, Toyooka Y, Shimosato D, Strumpf D, Takahashi K, Yagi R, Rossant J: Interaction between Oct3/4 and $\mathrm{Cd} \times 2$ determines trophectoderm differentiation. Cell 2005, 123:917-929.

14. Harvey AJ, Armant DR, Bavister BD, Nichols SM, Brenner CA: Inner cell mass localization of NANOG precedes OCT3/4 in rhesus monkey blastocysts. Stem Cells Dev 2009, 18:1451-1458.

15. Thomson JA, Itskovitz-Eldor J, Shapiro SS, Waknitz MA, Swiergiel JJ, Marshall VS, Jones JM: Embryonic stem cell lines derived from human blastocysts. Science 1998, 282:1145-1147.

16. Andrews PW, Bronson DL, Benham F, Strickland S, Knowles BB: A comparative study of eight cell lines derived from human testicular teratocarcinoma. Int J Cancer 1980, 26:269-280.

17. Andrews PW, Goodfellow PN, Shevinsky LH, Bronson DL, Knowles BB: Cellsurface antigens of a clonal human embryonal carcinoma cell line: morphological and antigenic differentiation in culture. Int J Cancer 1982, 29:523-531.

18. Andrews PW, Casper J, Damjanov I, Duggan-Keen M, Giwercman A, Hata J, von Keitz A, Looijenga LH, Millán JL, Oosterhuis JW, Pera M, Sawada M, Schmoll HJ, Skakkebaek NE, van Putten W, Stern P: Comparative analysis of cell surface antigens expressed by cell lines derived from human germ cell tumours. Int J Cancer 1996, 66:806-816.

19. Kannagi $R$, Cochran NA, Ishigami F, Hakomori S, Andrews PW, Knowles BB, Solter D: Stage-specific embryonic antigens (SSEA-3 and -4) are epitopes of a unique globo-series ganglioside isolated from human teratocarcinoma cells. EMBO J 1983, 2:2355-2361.

20. International Stem Cell Initiative, Adewumi O, Aflatoonian B, Ahrlund-Richter L, Amit M, Andrews PW, Beighton G, Bello PA, Benvenisty N, Berry LS, Bevan S, Blum B, Brooking J, Chen KG, Choo AB, Churchill GA, Corbel M, Damjanov I, Draper JS, Dvorak P, Emanuelsson K, Fleck RA, Ford A, Gertow K, Gertsenstein M, Gokhale PJ, Hamilton RS, Hampl A, Healy LE, Hovatta O, et al::

Characterization of human embryonic stem cell lines by the International Stem Cell Initiative. Nat Biotechnol 2007, 25:803-816.

21. Henderson JK, Draper JS, Baillie HS, Fishel S, Thomson JA, Moore H, Andrews
PW: Preimplantation human embryos and embryonic stem cells show comparable expression of stage-specific embryonic antigens. Stem Cells 2002, 20:329-337

22. Tesar PJ, Chenoweth JG, Brook FA, Davies TJ, Evans EP, Mack DL, Gardner RL, McKay RD: New cell lines from mouse epiblast share defining features with human embryonic stem cells. Nature 2007, 448:196-199.

23. Brons IG, Smithers LE, Trotter MW, Rugg-Gunn P, Sun B, Chuva de Sousa Lopes SM, Howlett SK, Clarkson A, Ahrlund-Richter L, Pedersen RA, Vallier L: Derivation of pluripotent epiblast stem cells from mammalian embryos. Nature 2007, 448:191-195.

24. Chou YF, Chen HH, Eijpe M, Yabuuchi A, Chenoweth JG, Tesar P, Lu J, McKay RD, Geijsen N: The growth factor environment defines distinct pluripotent ground states in novel blastocyst-derived stem cells. Cell 2008, 135:449-461

25. Hanna J, Cheng AW, Saha K, Kim J, Lengner CJ, Soldner F, Cassady JP, Muffat J, Carey BW, Jaenisch R: Human embryonic stem cells with biological and epigenetic characteristics similar to those of mouse ESCs. Proc Natl Acad Sci USA 2010, 107:9222-9227.

26. Lengner CJ, Gimelbrant AA, Erwin JA, Cheng AW, Guenther MG, Welstead GG, Alagappan R, Frampton GM, Xu P, Muffat J, Santagata S, Powers D, Barrett CB, Young RA, Lee JT, Jaenisch R, Mitalipova M: Derivation of Pre-X inactivation human embryonic stem cells under physiological oxygen concentrations. Cell 2010, 141:872-883

27. Gurdon JB: From nuclear transfer to nuclear reprogramming: the reversal of cell differentiation. Annu Rev Cell Dev Biol 2006, 22:1-22.

28. Briggs R, King TJ: Transplantation of living nuclei from blastula cells into enucleated frogs' eggs. Proc Natl Acad SciU S A 1952, 38:455-463.

29. Gurdon JB, Uehlinger V: "Fertile" intestine nuclei. Nature 1966, 210:1240-1241.

30. Wilmut I, Schnieke AE, McWhir J, Kind AJ, Campbell KH: Viable offspring derived from fetal and adult mammalian cells. Nature 1997, 385:810-813.

31. Hochedlinger $K$, Jaenisch R: Nuclear transplantation: lessons from frogs and mice. Curr Opin Cell Biol 2002, 14:741-748.

32. Cowan CA, Atienza J, Melton DA, Eggan K: Nuclear reprogramming of somatic cells after fusion with human embryonic stem cells. Science 2005, 309:1369-1373.

33. Taranger CK, Noer A, Sorensen AL, Hakelien AM, Boquest AC, Collas P: Induction of dedifferentiation, genomewide transcriptional programming, and epigenetic reprogramming by extracts of carcinoma and embryonic stem cells. Mol Biol Cell 2005, 16:5719-5735.

34. Davis RL, Weintraub H, Lassar AB: Expression of a single transfected cDNA converts fibroblasts to myoblasts. Cell 1987, 51:987-1000.

35. Xie H, Ye M, Feng R, Graf T: Stepwise reprogramming of B cells into macrophages. Cell 2004, 117:663-676.

36. Takahashi K, Yamanaka S: Induction of pluripotent stem cells from mouse embryonic and adult fibroblast cultures by defined factors. Cell 2006, 126:663-676

37. Takahashi K, Tanabe K, Ohnuki M, Narita M, Ichisaka T, Tomoda K, Yamanaka S: Induction of pluripotent stem cells from adult human fibroblasts by defined factors. Cell 2007, 131:861-872

38. Yu J, Vodyanik MA, Smuga-Otto K, Antosiewicz-Bourget J, Frane JL, Tian S, Nie J, Jonsdottir GA, Ruotti V, Stewart R, Slukvin II, Thomson JA: Induced pluripotent stem cell lines derived from human somatic cells. Science 2007, 318:1917-1920.

39. Chan EM, Ratanasirintrawoot $\mathrm{S}$, Park IH, Manos PD, Loh YH, Huo H, Miller JD, Hartung O, Rho J, Ince TA, Daley GQ, Schlaeger TM: Live cell imaging distinguishes bona fide human iPS cells from partially reprogrammed cells. Nat Biotechnol 2009, 27:1033-1037.

40. Yu J, Hu K, Smuga-Otto K, Tian S, Stewart R, Slukvin, II, Thomson JA: Human induced pluripotent stem cells free of vector and transgene sequences. Science 2009, 324:797-801.

41. Jia F Wilson KD, Sun N, Gupta DM, Huang M, Li Z, Panetta NJ Chen ZY, Robbins RC, Kay MA, Longaker MT, Wu JC: A nonviral minicircle vector for deriving human iPS cells. Nat Methods 2010, 7:197-199.

42. Kaji K, Norrby K, Paca A, Mileikovsky M, Mohseni P, Woltjen K: Virus-free induction of pluripotency and subsequent excision of reprogramming factors. Nature 2009 , 458:771-775.

43. Woltjen K, Michael IP, Mohseni P, Desai R, Mileikovsky M, Hämäläinen R, Cowling R, Wang W, Liu P, Gertsenstein M, Kaji K, Sung HK, Nagy A: piggyBac transposition reprograms fibroblasts to induced pluripotent stem cells. Nature 2009, 458:766-770. 
44. Kim D, Kim CH, Moon Jl, Chung YG, Chang MY, Han BS, Ko S, Yang E, Cha KY, Lanza R, Kim KS: Generation of human induced pluripotent stem cells by direct delivery of reprogramming proteins. Cell Stem Cell 2009, 4:472-476.

45. Zhou H, Wu S, Joo JY, Zhu S, Han DW, Lin T, Trauger S, Bien G, Yao S, Zhu Y, Siuzdak G, Schöler HR, Duan L, Ding S: Generation of induced pluripotent stem cells using recombinant proteins. Cell Stem Cell 2009, 4:381-384.

46. Cho HJ, Lee CS, Kwon YW, Paek JS, Lee SH, Hur J, Lee EJ, Roh TY, Chu IS, Leem SH, Kim Y, Kang HJ, Park YB, Kim HS: Induction of pluripotent stem cells from adult somatic cells by protein-based reprogramming without genetic manipulation. Blood 2010, 116:386-395.

47. Heng JC, Feng B, Han J, Jiang J, Kraus P, Ng JH, Orlov YL, Huss M, Yang L, Lufkin T, Lim B, Ng HH: The nuclear receptor Nr5a2 can replace Oct4 in the reprogramming of murine somatic cells to pluripotent cells. Cell Stem Cell 2010, 6:167-174

48. Pardo M, Lang B, Yu L, Prosser H, Bradley A, Babu MM, Choudhary J: An expanded Oct4 interaction network: implications for stem cell biology, development, and disease. Cell Stem Cell 2010, 6:382-395

49. Egli D, Rosains J, Birkhoff G, Eggan K: Developmental reprogramming after chromosome transfer into mitotic mouse zygotes. Nature 2007, 447:679-685.

50. Kim JB, Greber B, Arauzo-Bravo MJ, Meyer J, Park KI, Zaehres H, Scholer HR: Direct reprogramming of human neural stem cells by OCT4. Nature 2009, 461:649-643.

51. Utikal J, Maherali N, Kulalert W, Hochedlinger K: Sox2 is dispensable for the reprogramming of melanocytes and melanoma cells into induced pluripotent stem cells. J Cell Sci 2009, 122:3502-3510.

52. Masui $S$, Nakatake Y, Toyooka Y, Shimosato D, Yagi R, Takahashi K, Okochi H, Okuda A, Matoba R, Sharov AA, Ko MS, Niwa H: Pluripotency governed by Sox2 via regulation of Oct3/4 expression in mouse embryonic stem cells. Nat Cell Bio/ 2007, 9:625-635.

53. Maherali N, Hochedlinger K: Tgfbeta signal inhibition cooperates in the induction of iPSCs and replaces Sox2 and cMyc. Curr Bio/ 2009, 19:1718-1723.

54. Ichida JK, Blanchard J, Lam K, Son EY, Chung JE, Egli D, Loh KM, Carter AC, Di Giorgio FP, Koszka K, Huangfu D, Akutsu H, Liu DR, Rubin LL, Eggan K: A small-molecule inhibitor of tgf-Beta signaling replaces sox 2 in reprogramming by inducing nanog. Cell Stem Cell 2009, 5:491-503.

55. Nakatake Y, Fukui N, Iwamatsu Y, Masui S, Takahashi K, Yagi R, Yagi K, Miyazak J, Matoba R, Ko MS, Niwa H: KIf4 cooperates with Oct3/4 and Sox2 to activate the Lefty 1 core promoter in embryonic stem cells. Mol Cell Biol 2006, 26:7772-7782

56. Niwa H, Ogawa K, Shimosato D, Adachi K: A parallel circuit of LIF signalling pathways maintains pluripotency of mouse ES cells. Nature 2009, 460:118-122.

57. Kim J, Chu J, Shen X, Wang J, Orkin SH: An extended transcriptional network for pluripotency of embryonic stem cells. Cell 2008, 132:1049-1061.

58. Guo G, Yang J, Nichols J, Hall JS, Eyres I, Mansfield W, Smith A: Klf4 reverts developmentally programmed restriction of ground state pluripotency. Development 2009, 136:1063-1069.

59. Nakagawa M, Koyanagi M, Tanabe K, Takahashi K, Ichisaka T, Aoi T, Okita K, Mochiduki Y, Takizawa N, Yamanaka S: Generation of induced pluripotent stem cells without Myc from mouse and human fibroblasts. Nat Biotechnol 2008, 26:101-106.

60. Judson RL, Babiarz JE, Venere M, Blelloch R: Embryonic stem cell-specific microRNAs promote induced pluripotency. Nat Biotechnol 2009, 27:459-461.

61. Lin CH, Jackson AL, Guo J, Linsley PS, Eisenman RN: Myc-regulated microRNAs attenuate embryonic stem cell differentiation. EMBO J 2009, 28:3157-3170.

62. Laurenti E, Wilson A, Trumpp A: Myc's other life: stem cells and beyond. Curr Opin Cell Biol 2009, 21:844-854.

63. Chambers I, Silva J, Colby D, Nichols J, Nijmeijer B, Robertson M, Vrana J, Jones K, Grotewold L, Smith A: Nanog safeguards pluripotency and mediates germline development. Nature 2007, 450:1230-1234.

64. Hanna J, Saha K, Pando B, van Zon J, Lengner CJ, Creyghton MP, van Oudenaarden A, Jaenisch R: Direct cell reprogramming is a stochastic process amenable to acceleration. Nature 2009, 462:595-601.

65. Hagan JP, Piskounova E, Gregory RI: Lin28 recruits the TUTase Zcchc11 to inhibit let-7 maturation in mouse embryonic stem cells. Nat Struct Mol Biol 2009, 16:1021-1025

66. Papapetrou EP, Tomishima MJ, Chambers SM, Mica Y, Reed E, Menon J, Tabar
V, Mo Q, Studer L, Sadelain M: Stoichiometric and temporal requirements of Oct4, Sox2, KIf4, and c-Myc expression for efficient human iPSC induction and differentiation. Proc Natl Acad Sci U S A 2009, 106:12759-12764.

67. Li R, Liang J, Ni S, Zhou T, Qing X, Li H, He W, Chen J, Li F, Zhuang Q, Qin B, Xu J, Li W, Yang J, Gan Y, Qin D, Feng S, Song H, Yang D, Zhang B, Zeng L, Lai L, Esteban MA, Pei D: A mesenchymal-to-epithelial transition initiates and is required for the nuclear reprogramming of mouse fibroblasts. Cell Stem Cell 2010, 7:51-63.

68. Samavarchi-Tehrani P, Golipour A, David L, Sung H, Beyer TA, Datti A, Woltjen K, Nagy A, Wrana JL: Functional genomics reveals a BMP-driven mesenchymal-to-epithelial transition in the initiation of somatic cell reprogramming. Cell Stem Cell 2010, 7:64-77.

69. Bernstein BE, Mikkelsen TS, Xie X, Kamal M, Huebert DJ, Cuff J, Fry B, Meissner A, Wernig M, Plath K, Jaenisch R, Wagschal A, Feil R, Schreiber SL, Lander ES: A bivalent chromatin structure marks key developmental genes in embryonic stem cells. Cell 2006, 125:315-326.

70. Mikkelsen TS, Hanna J, Zhang X, Ku M, Wernig M, Schorderet P, Bernstein BE, Jaenisch $R$, Lander ES, Meissner A: Dissecting direct reprogramming through integrative genomic analysis. Nature 2008, 454:49-55

71. Miyoshi N, Ishii H, Nagai K, Hoshino H, Mimori K, Tanaka F, Nagano H, Sekimoto M, Doki Y, Mori M: Defined factors induce reprogramming of gastrointestinal cancer cells. Proc Natl Acad Sci U S A 2010, 107:40-45.

72. Aoi T, Yae K, Nakagawa M, Ichisaka T, Okita K, Takahashi K, Chiba T, Yamanaka S: Generation of pluripotent stem cells from adult mouse liver and stomach cells. Science 2008, 321:699-702.

73. Aasen T, Raya A, Barrero MJ, Garreta E, Consiglio A, Gonzalez F, Vassena R, Bilić J, Pekarik V, Tiscornia G, Edel M, Boué S, Izpisúa Belmonte JC: Efficient and rapid generation of induced pluripotent stem cells from human keratinocytes. Nat Biotechno/ 2008, 26:1276-1284.

74. Eminli S, Foudi A, Stadtfeld M, Maherali N, Ahfeldt T, Mostoslavsky G, Hock H, Hochedlinger K: Differentiation stage determines potential of hematopoietic cells for reprogramming into induced pluripotent stem cells. Nat Genet 2009, 41:968-976.

75. Huangfu D, Maehr R, Guo W, Eijkelenboom A, Snitow M, Chen AE, Melton DA Induction of pluripotent stem cells by defined factors is greatly improved by small-molecule compounds. Nat Biotechno/ 2008, 26:795-797.

76. Shi Y, Do JT, Desponts C, Hahm HS, Scholer HR, Ding S: A combined chemical and genetic approach for the generation of induced pluripotent stem cells. Cell Stem Cell 2008, 2:525-528.

77. Kim K, Doi A, Wen B, Ng K, Zhao R, Cahan P, Kim J, Aryee MJ, Ji H, Ehrlich LI, Yabuuchi A, Takeuchi A, Cunniff KC, Hongguang H, McKinney-Freeman S, Naveiras O, Yoon TJ, Irizarry RA, Jung N, Seita J, Hanna J, Murakami P, Jaenisch R, Weissleder R, Orkin SH, Weissman IL, Feinberg AP, Daley GQ: Epigenetic memory in induced pluripotent stem cells. Nature 2010 [Epub ahead of print]

78. Polo JM, Liu S, Figueroa ME, Kulalert W, Eminli S, Tan KY, Apostolou E, Stadtfeld M, Li Y, Shioda T, Natesan S, Wagers AJ, Melnick A, Evans T, Hochedlinger K: Cell type of origin influences the molecular and functional properties of mouse induced pluripotent stem cells. Nat Biotechno/ 2010, 28:848-855.

79. Stadtfeld M, Apostolou E, Akutsu H, Fukuda A, Follett P, Natesan S, Kono T, Shioda T, Hochedlinger K: Aberrant silencing of imprinted genes on chromosome 12qF1 in mouse induced pluripotent stem cells. Nature 2010 , 465:175-181.

80. Liu L, Luo GZ, Yang W, Zhao X, Zheng Q, Lv Z, Li W, Wu HJ, Wang L, Wang XJ, Zhou Q: Activation of the imprinted Dlk1-Dio3 region correlates with pluripotency levels of mouse stem cells. J Biol Chem 2010, 285:19483-19490.

81. Han J, Yuan P, Yang H, Zhang J, Soh BS, Li P, Lim SL, Cao S, Tay J, Orlov YL, Lufkin T, Ng HH, Tam WL, Lim B: Tbx3 improves the germ-line competency of induced pluripotent stem cells. Nature 2010, 463:1096-1100.

82. Pick M, Stelzer Y, Bar-Nur O, Mayshar Y, Eden A, Benvenisty N: Clone- and gene-specific aberrations of parental imprinting in human induced pluripotent stem cells. Stem Cells 2009, 27:2686-2690.

83. Urbach A, Bar-Nur O, Daley GQ, Benvenisty N: Differential modeling of fragile $X$ syndrome by human embryonic stem cells and induced pluripotent stem cells. Cell Stem Cell 2010, 6:407-411.

84. Stefani G, Slack FJ: Small non-coding RNAs in animal development. Nat Rev Mol Cell Biol 2008, 9:219-230.

85. Roush S, Slack FJ: The let-7 family of microRNAs. Trends Cell Biol 2008, 18:505-516.

86. Heo I, Joo C, Cho J, Ha M, Han J, Kim VN: Lin28 mediates the terminal uridylation of let-7 precursor MicroRNA. Mol Cell 2008, 32:276-284. 
87. Viswanathan SR, Daley GQ, Gregory Rl: Selective blockade of microRNA processing by Lin28. Science 2008, 320:97-100.

88. Zhao Y, Yin X, Qin H, Zhu F, Liu H, Yang W, Zhang Q, Xiang C, Hou P, Song Z, Liu Y, Yong J, Zhang P, Cai J, Liu M, Li H, Li Y, Qu X, Cui K, Zhang W, Xiang T, Wu Y, Zhao Y, Liu C, Yu C, Yuan K, Lou J, Ding M, Deng H: Two supporting factors greatly improve the efficiency of human iPSC generation. Cell Stem Cell 2008, 3:475-479.

89. Banito A, Rashid ST, Acosta JC, Li S, Pereira CF, Geti I, Pinho S, Silva JC, Azuara $\checkmark$, Walsh $M$, Vallier L, Gil J: Senescence impairs successful reprogramming to pluripotent stem cells. Genes Dev 2009, 23:2134-2139.

90. Utikal J, Polo JM, Stadtfeld M, Maherali N, Kulalert W, Walsh RM, Khalil A, Rheinwald JG, Hochedlinger K: Immortalization eliminates a roadblock during cellular reprogramming into iPS cells. Nature 2009, 460:1145-1148.

91. Li H, Collado M, Villasante A, Strati K, Ortega S, Canamero M, Blasco MA, Serrano M: The Ink4/Arf locus is a barrier for iPS cell reprogramming. Nature 2009, 460:1136-1139.

92. Marion RM, Strati K, Li H, Murga M, Blanco R, Ortega S, Fernandez-Capetillo O, Serrano M, Blasco MA: A p53-mediated DNA damage response limits reprogramming to ensure iPS cell genomic integrity. Nature 2009, 460:1149-1153.

93. Hong H, Takahashi K, Ichisaka T, Aoi T, Kanagawa O, Nakagawa M, Okita K, Yamanaka S: Suppression of induced pluripotent stem cell generation by the p53-p21 pathway. Nature 2009, 460:1132-1135.

94. Kawamura T, Suzuki J, Wang YV, Menendez S, Morera LB, Raya A, Wahl GM, Belmonte JC: Linking the p53 tumour suppressor pathway to somatic cell reprogramming. Nature 2009, 460:1140-1144.

95. Esteban MA, Wang T, Qin B, Yang J, Qin D, Cai J, Li W, Weng Z, Chen J, Ni S, Chen K, Li Y, Liu X, Xu J, Zhang S, Li F, He W, Labuda K, Song Y, Peterbauer A, Wolbank S, Redl H, Zhong M, Cai D, Zeng L, Pei D: Vitamin C enhances the generation of mouse and human induced pluripotent stem cells. Cell Stem Cell 2009, 6:71-79.

96. Digweed M, Demuth I, Rothe S, Scholz R, Jordan A, Grotzinger C, Schindler D, Grompe M, Sperling K: SV40 large T-antigen disturbs the formation of nuclear DNA-repair foci containing MRE11. Oncogene 2002, 21:4873-4878.
97. Mali P, Ye Z, Hommond HH, Yu X, Lin J, Chen G, Zou J, Cheng L: Improved efficiency and pace of generating induced pluripotent stem cells from human adult and fetal fibroblasts. Stem Cells 2008, 26:1998-2005.

98. Chin MH, Mason MJ, Xie W, Volinia S, Singer M, Peterson C, Ambartsumyan G, Aimiuwu O, Richter L, Zhang J, Khvorostov I, Ott V, Grunstein M, Lavon N, Benvenisty N, Croce CM, Clark AT, Baxter T, Pyle AD, Teitell MA, Pelegrini M, Plath K, Lowry WE: Induced pluripotent stem cells and embryonic stem cells are distinguished by gene expression signatures. Cell Stem Cell 2009, 5:111-123.

99. Doi A, Park IH, Wen B, Murakami P, Aryee MJ, Irizarry R, Herb B, Ladd-Acosta C, Rho J, Loewer S, Miller J, Schlaeger T, Daley GQ, Feinberg AP: Differential methylation of tissue- and cancer-specific $\mathrm{CpG}$ island shores distinguishes human induced pluripotent stem cells, embryonic stem cells and fibroblasts. Nat Genet 2009, 41:1350-1353.

100. Feng Q, Lu SJ, Klimanskaya I, Gomes I, Kim D, Chung Y, Honig GR, Kim KS, Lanza R: Hemangioblastic derivatives from human induced pluripotent stem cells exhibit limited expansion and early senescence. Stem Cells 2010 28:704-712.

101. Unger C, Skottman H, Blomberg P, Dilber MS, Hovatta O: Good manufacturing practice and clinical-grade human embryonic stem cell lines. Hum Mol Genet 2008, 17:R48-53.

102. Daley GQ, Scadden DT: Prospects for stem cell-based therapy. Cell 2008, 132:544-548.

103. Kiskinis E, Eggan K: Progress toward the clinical application of patientspecific pluripotent stem cells. J Clin Invest 2010, 120:51-59.

doi:10.1186/scrt33

Cite this article as: Na J, et al.: Molecular mechanisms of pluripotency and reprogramming. Stem Cell Research \& Therapy 2010, 1:33. 